\title{
Túl az etikán - a humán kutatások kockázatérzékenysége és pszichológiai aspektusai
}

\author{
Csépe Valéria \\ Eötvös Loránd Kutatási Hálózat, Természettudományi Kutatóközpont, Agyi Képalkotó Központ, \\ Budapest, Magyarország \\ Összefoglalás
}

\begin{abstract}
A humán kutatások eredményeit bemutató közlemények számos adattal szolgálnak a megismerni kívánt jelenségre vonatkozóan. Általánosan elfogadott elvárás a vonatkozó etikai szabályok szigorú betartása, az előírt vizsgálati protokollok betartása. Az emberekkel végzett vizsgálatoknak azonban van egy olyan dimenziója, amelyre az etikai szabályok nem térnek ki, s amelyek a vizsgálati eredményeket, illetve azok reprezentativitását is befolyásolják. Ezek mindegyike a pszichológia vizsgálódási területéhez tartozik, legyen szó a pszichológiai kutatások etikai kérdéseiről, vagy az orvosbiológiai kutatások, orvosi beavatkozások, illetve azok elfogadásának pszichológiai aspektusairól. A tanulmány a pszichológia megváltozott etikai felfogásának rövid bemutatását követően a genetikai kutatások pszichológiai aspektusait és az egészség-magatartás kritikus kérdéseit elemzi. Az utóbbiak esetében a kockázatészlelés, valamint a bizalom, megbízhatóság pszichológiai modelljeiből kiindulva mutatja be az oltási hajlandóság és az oltásellenesség ismert pszichológiai faktorait.
\end{abstract}

Kulcsszavak: pszichológia, etika, morál, genetika, egészség-magatartás, kockázatészlelés, oltási hajlandóság, vakcinatagadás

\section{Beyond ethics - risk sensitivity and psychological aspects of human research Valéria Csépe}

ELKH RCNS, Brain Imaging Centre, Budapest, Hungary

\begin{abstract}
Summary
Publications presenting the results of human research provide a wealth of data on the phenomenon to be explored. It is a generally accepted expectation to adhere strictly to the relevant ethical rules and to the required protocols. However, studies in humans have a dimension that is not fully covered by ethical rules and that also affects the studies' results and their representativeness. All of these belong to the field of research in psychology, be it the ethical issues of psychological research or the psychological aspects of biomedical research, medical interventions, and their acceptance. Researchers of these and other scientific areas widely believe that science is morally neutral, that is, its task is the discovery of facts, the further development of the investigations' tools and methods to perform correct analysis and draw reliable conclusions. However, research and development are characterized by a kind of moral neutrality, the essence of which is that the researcher not participating in the decisions on applications is neutral in general. This means that the curiosity driven research should not pay attention to risks associated with the use of results. However, many recent concerns related to the long-term effects of broadly applied inventions speaks for the need on consensus how the consequences could or should be forecasted.

Following a brief presentation of the changed ethical perception of psychology, I give some examples on the psychological aspects of genetic research and that of the critical issues in health behavior. Concerns psychological in nature have been articulated in the last decade and it became increasingly clear that genetic testing can also have psychological factors that must be considered. Moreover, the recent focus on psychological aspects of human research shed light on the complexity of health behavior, and questions have been raised about the known psychological factors of the human reactions to suggested therapies, especially those of the vaccination propensity, rejection, and anti-vaccination movements. Although there are only a few systematic studies on this issue, the proper solutions of the Covid-19 should consider the psychological aspects of the acceptance and rejection of vaccination. We may con-
\end{abstract}


sider that the first waves of the Covid-19 epidemic created situations requiring altered psychological coping, to which psychological research responded primarily by examining the epidemiological situation, illness, and the resulting psychological aspects of lifestyle (treatment of social isolation, stress management, anxiety, depression). Therefore, scientific data on risk perception and psychological factors of vaccine acceptance may contribute to preparedness for globally predicted epidemics and decision-making processes.

Keywords: ethics, morality, psychological factors, genetic testing, health behavior, risk perception, vaccine acceptance, rejection, psychology of anti-vaccine movements

\section{Bevezetés}

A tudomány elmúlt évtizedei jelentős változást hoztak a kutatásetikában, s valamennyi kutatási terület, kiemelten pedig az empirikus vizsgálatok esetében a tervezés és kivitelezés etikai szabályai (code of conduct) jelentős változáson mentek át. Kérdés azonban, hogy a tudomány múvelőinek kizárólag az aktuális kutatások etikai előírásaira kell-e figyelniük, azaz szükséges lehet-e, s ha igen, milyen konkrét elvárások alapján lehetséges az alkalmazást megelőzően az adott területen túl (például környezeti terhelés) a közép- és hosszú távú hatást modellezni. Régi dilemmát fogalmaz meg az a kérdés, hogy van-e, s ha igen, miként gyakorolható a tudományos előrelátás, a kutató, fejlesztő felelőssége túlmutat-e az etikán, azaz létezik-e morális, hosszú távon érvényes elvárás is. Sok kutató széles körben vallja, hogy a tudomány erkölcsileg semleges, azaz feladata a megismerés, s ebben a tények feltárásának, a kutatás szükséges eszközeinek és módszereinek kialakítása, továbbfejlesztése, a korrekt elemzés és következtetés a meghatározó. A kutatást és fejlesztést egyfajta morális semlegesség jellemzi, s ennek lényege, hogy a kutató az ismertté tett eredmények felhasználásához kapcsolódó kockázatokra vonatkozó döntésben nem vesz részt. Az alkalmazás a társadalom más feladatrendszereiben múködő felhasználók anyagi, társadalmi és erkölcsi felelősségét. Albert Einstein szerint: „A tudomány csak meg tudja állapítani, hogy mi van, de azt nem, aminek lennie kell.” Ebből az is következik, hogy egy adott tudományos közösség saját szakterületén kívüli másfajta értékítélet múködik, a hasznosság és hasznosulás szempontjai pedig nem feltétlenül vezetnek tudásalapú döntésekhez.

Feltehető, hogy a tudomány adott fejlettségi szintjének megfelelő tudásra épülő új technológiák hosszú távú kockázatokat hordozhatnak. Ennek egyik oka, hogy a tudomány folyamatosan változik, s vele az aktuális tudás is. A hosszabb távú előrelátást nehezíti, hogy a tudományágak évtizedeken át részben érintkező tudásrendszereit csak újabban alakítja át a multidiszciplináris szemlélet. Ennek egyik jellegzetes példája, s a globális hatások miatt egyre fontosabb területe, a környezettudomány, amely több tudományág tudására támaszkodva fogalmazza meg a fenntarthatóság biztonsági kérdéseit is.

A kutatással járó kockázatok elkerülésének szakmai és etikai szabályai minden tudományágban meghatározásra kerültek, s egyes területeken folyamatosan szigorodnak. Az etikai kódexekben, kutatásetikai engedélyekben, pro- tokollokban rögzített etikai szabályok betartása a tudományok minden múvelője számára kötelező. A morális kérdések kezelése azonban kevésbé határozott, s nehezen is megragadható. Ennek egyik oka, hogy támogató társadalmi közegben a tudományágak képviselői megengedhetik maguknak a függetlenséget abban is, hogy semleges álláspontot képviseljenek erkölcsi természetü kérdésekben. A totalitárius társadalmakban más a helyzet, s ez számos biztonsági kérdést vet fel, legyen szó kutatási adatokról, vagy éppen eredményekhez való nyílt hozzáférésről. Bár ez a kérdés szélsőséges, ám nem ritka problémákra irányul, a leggyakoribb felvetés inkább az, hogy a kutatás új eredményeinek alkalmazásakor, beleértve az alternatív energiák bevezetését megalapozó kutatást és fejlesztést, valamint a 21 . századi jóllétet meghatározó technológiákat, számításba vesszük-e ezek következményeit. A kutatás, fejlesztés és innováció eredményeinek felhasználásából következő jólétünk (wealth) és jóllétünk (well-being) nem értelmezhető önmagában, hiszen a tudományos eredmények elterjedt alkalmazásának következményei csak részben láthatóak egy adott időpontban.

A kutatás kockázatérzékenységét nem csupán a belátható idő hossza határozza meg, hanem egy adott korszak tudományetikai alapvetése, elvárásrendszere is. Ez jól megfigyelhető a humán tudományok területén, amelyek közül itt a pszichológiai kutatások néhány példáján igyekszem bemutatni azt a folyamatosan változó alapvetést, amely az emberi méltóság iránti érzékenységgel és a kockázatészleléssel párhuzamosan változik.

\section{Etikai alapelvek és a kutatásetika új korszaka}

Bár a kutatásetikában számos jól ismert alapelv érvényesül, itt most hármat emelek ki közülük. Az első a kutatásban részt vevők autonómiájának tiszteletben tartása, amelyet a szabad, tájékozott és folyamatos beleegyezés biztosít. Az autonómia érvényesítése magában foglalja azok védelmét is, akik ezt nem, vagy korlátozottan tudják gyakorolni. Ide tartoznak a kiskorúak, fiatalkorúak, a kognitív károsodással, mentális egészségi problémával, neurodegeneratív betegségekkel küzdők. Az utóbbiak egyes vizsgálatokban való részvétele rövid és hosszú távú biztonsági kockázattal is járhat. A második, s az elsőhöz képest nehezebben kezelhető alapelv a jóléttel (welfare) és jól-léttel (well-being) kapcsolatos. Ennek az alapelv- 
nek a lényege, hogy a résztvevőket ne tegyük ki szükségtelen kockázatoknak. Ebbe beletartozik a résztvevők magánélete, az információk titkos kezelése, valamint minden olyan információ biztosítása, amelynek alapján megfelelően értékelhető a részvétel kockázata, valamint lehetséges hátrányai és előnyei. A harmadik az igazságosság alapelve, azaz a tisztességes és méltányos bánásmód, egyes résztvevők kiszolgáltatottságának figyelembevétele. Talán felesleges kiemelni azt a tényt, hogy ezek az elvek egyaránt vonatkoznak a kutatásban részt vevőkre, a tudományos közösségre és a társadalomra.

A tudományetikai alapelvek fenti rövid leírásából úgy tûnhet, egyértelmû az, hogy mi az etikus kutatás és mi nem. Mégis, a pszichológiai kutatások néhány évtizedére visszatekintve megállapítható, hogy a kutatók számára időnként elmosódik az a határ, amely az etikai alapelvek betartása és a tudományos megismerés érdekei között húzódik. Példaként érdemes megemlíteni az autoritásnak való engedelmeskedés elhíresült vizsgálatát (Milgram 1963). A résztvevők azt a tájékoztatást kapták, hogy a kutatásban a büntetés tanulásra gyakorolt hatását vizsgálják. Ez valóban így volt, csak éppen a vizsgálat úgy történt, hogy a résztvevők egyik csoportja arra kapott utasítást, hogy áramütést adjon a tanulási feladatban részt vevőknek, ha helytelenül válaszoltak egy tanult feladatra. Az áramütés erőssége a helytelen válaszok számával arányosan nőtt. Az áramütéssel büntetett résztvevő tiltakozására, fájdalomjelzésére megjelenő habozás vagy aggodalom esetén a vizsgálatot vezető kutató a folytatásra biztatta a büntetést gyakorló résztvevőt. Bár a valóságban a „büntetett” résztvevő a kutató beavatott együttmúködője volt, valódi résztvevőként jelezte fájdalmát. A kutatás meglepő eredménye az volt, hogy a legtöbb résztvevő a büntetett személy tiltakozása, panasza, fájdalomkiáltásai ellenére folytatta az áramütéssel történő büntetést.

Milgram 1963-as tanulmányát ma a pszichológia a kutatások elrettentő etikai eseteként értékeli. Érdekes ugyanakkor megjegyeznünk, hogy a kutatás etikai megítéléséról folytatott viták egyik kérdése az volt, hogy az így szerzett tudományos ismeretek megérték-e a kutatás résztvevőinek okozott kárt. Kérdés, hogy a kár valójában csak abban nyilvánul-e meg, hogy a kontrollt gyakorlók többsége pszichés és élettani tünetek sokaságát produkálta-e, vagy abban, hogy egy részük sajátos érzéketlenséget mutatott. Bár a résztvevők pszichés reakciói rendeződtek, nem tudni, hogy a kutatásban szerzett tapasztalatok miként hatottak később. Bármi legyen is a Milgram-féle kutatás tudományos felismerést hozó értéke, a mai etikai standardoknak nem felel meg, sérül az autonómia és a jólét figyelembevételének alapelve.

Az igazságosság alapelve is több kutatásban is sérült és sérülhet ma is. Így például egy új és várhatóan előnyös pszichoterápia hatásvizsgálatában a résztvevők egyik csoportja a terápiás, a másik pedig a kontrollcsoport tagjaiként szolgálnak, amely nem részesül kezelésben. Ha a pszichoterápia eredményesnek bizonyul, méltányos azt felajánlani a kontrollcsoport résztvevőinek is a vizsgálat befejezését követően. További kérdés, s mindhárom alapelv érvényesülése alapos elemzést érdemelne azokban az esetekben, amelyekben nagy léptékü változások, környezetei katasztrófák, járványok (lásd a COVID-19 pandémiát) pszichológiai hatásait kívánja a pszichológia vizsgálni. Ezekben az esetekben nemegyszer felmerülnek az etikai normákon túlmutató morális dilemmák is. Tény ugyanakkor, hogy a pszichológiai kutatásokban igen nehéz az etikai konfliktusokat elkerülni.

\section{Elkerülhetetlen etikai konfliktusok a pszichológiai kutatásokban}

Elkerülhetők-e az etikai konfliktusok a pszichológiai kutatásokban? Úgy tûnik, hogy nem teljesen, hiszen kevés kockázatmentes pszichológiai kutatás van, így a kockázatok és az előnyök között szinte mindig konfliktus lesz. Az egyik csoport, például a tudományos közösség számára elónyös, új ismereteket hozó kutatások károsak lehetnek a másikra, nevezetesen a kutatás résztvevőire. Az már ismét morális kérdés, hogy milyen mértékú lehet a kompromisszum, különösen, ha az etikai kérdések harmadik célcsoportjának, a társadalomnak az előnyeit is figyelembe kellene venni. Emellett az is igaz lehet egyes kutatásokban, hogy a kutatásban adott instrukció megnehezítheti vagy ellehetetlenítheti azt, hogy tudományosan megalapozott következtetésekre jussunk egyes kérdésekben. Nem szabad megfeledkeznünk arról, hogy egy pszichológiai kutatásban a vizsgált kérdésre sokszor nem adnak direkt választ az adatok, mert számos más tényező (észlelési, gondolkodási sajátosságok, kulturális eltérések stb.) is befolyásolhatja az eredményeket.

Természetesen sok etikai konfliktust könnyen meg lehet(ne) oldani. Szinte mindenki egyetért abban, hogy a kutatásban részt vevók megtévesztése, lelki, fizikai sérülése nem indokolható azzal, hogy a vonatkozó szakirodalomból már csak ez az apró kiegészítés hiányzik. Mégis sok olyan etikai konfliktus keletkezik, amit nem könnyú megoldani, legyenek a kutatók bármennyire hozzáértők és jó szándékúak. Gondoljunk például egy nyilvános férfi mosdóban folytatott kutatásra, amelynek célja a „személyes tér" vizsgálata. A példa nem kitalált, ugyanis egy több mint négy évtizede publikált kutatásban (Middlemist-Knowles-Matter 1976) titokban figyelték meg a kutatás alanyait, mégpedig egy férfi mosdóban. A megfigyelés célja az volt, hogy a mosdóban tartózkodók miként viselkednek egyedül, illetve a kutatás más résztvevőinek (a kutatók által beavatott személyek) jelenlétében. A kutatás etikai értékelése nem egyértelmú, mert sokan az eljárást az emberi méltóság indokolatlan támadásaként értékelték, míg mások szerint a kutatás előnyei meghaladták a kockázatot. Mindenesetre a pszichológiai kutatások jelenlegi standardjai szerint az etikai elvárások itt is sérülnek, különösen, hogy az emberi méltóság egy különleges aspektusáról, a személyes térról van szó. Észre kell ugyanakkor vennünk, hogy nem csupán a pszi- 
chológia kérdéseire választ kereső kutatások gerjeszthetnek pszichológiai természetú etikai konfliktust. Ennek oka pedig az, hogy minden humán résztvevőkkel folytatott kutatásnak van pszichológiai aspektusa, s ezek gyakran túlmutatnak az adott kutatási területen betartandó etikai szabályokon.

\section{Genetikai tesztelés és kutatás - pszichológiai válaszok}

A legtöbb dilemmával járó pszichológiai kérdések a biotechnológia fejlődésének elmúlt két évtizedében fogalmazódtak meg, kiemelten a klinikai genetikai területén. A magzatkori genetikai tesztelés kezdetei például a reproduktív döntéshozatalra összpontosítottak, majd a tanácsadás fókusza a személyes kockázat csökkentésére helyeződött át. Ezzel párhuzamosan egyre inkább felmerült, hogy a genetikai tesztelésnek olyan pszichológiai kockázatai is lehetnek, amelyeket mindenképpen figyelembe kell venni. A genetikai vizsgálatokhoz kapcsolódó pszichológiai kérdések átfogó elemzése (Oliveri et al. 2018) azt mutatta, hogy viszonylag kevés olyan örökletes betegség van, amelynek megismert kockázata súlyos pszichés választ váltana ki.

A jelenleg ismert kutatási adatokból arra következtethetünk, hogy a genetikai kockázatokkal kapcsolatos kommunikáció mélyen befolyásolhatja az emberek életét és szokásait. A genetikai tesztek pszichológiai hatásaival kapcsolatos tanulmányok egy része a genetikai kockázatokról szóló információk megismeréséhez kapcsolódó negatív reakciókra, például a szorongásra, depresszióra összpontosítottak (Oliveri et al. 2016), és szignifikáns választ a súlyos neurodegeneratív betegségek esetében találtak. Több kutatás szerint számos örökletes betegség kockázatának ismerete alig vagy egyáltalán nincs hatással az egészséggel kapcsolatos viselkedésre (Heshka et al. 2008; Hollands et al. 2016). Fontos azonban figyelembe vennünk, hogy a genetikai tesztek hatása attól is függ, hogy az emberek hogyan érzékelik egy adott betegség kockázatát, súlyosságát és a génkifejeződés befolyásolhatóságát (Cameron-Muller 2009; Wang et al. 2009; Wade et al. 2012).

\section{Az oltási hajlandóság pszichológiai aspektusai}

Bár a 20. század egyik legnagyobb közegészségügyi eredménye a fertőző betegségek elleni oltás megjelenése és a hatékony vakcinák számának folyamatos növekedése, az oltástagadás a kezdetektől fogva jelen van, s veszélyeztet sokakat. A tudomány múvelői számára megdöbbentő lehet, hogy az oltóanyagok fejlesztése, s különösen az oltási programok milyen ellenállásba ütköznek. 2020ig, a COVID-19-járvány kezdetéig a fejlett országok kutatóit a csecsemő- és kisgyermekkori védőoltásokkal szembeni ellenállás okai foglalkoztatták a legerőteljeseb- ben. A vakcinákkal szembeni bizalmatlanság nem csupán egészségügyi megfontolásokra támaszkodik, ezért érdemes lehet megvizsgálnunk azokat a pszichológiai tényezőket, amelyek az orvostudomány ezen vívmányainak kétségbe vonását befolyásolhatják.

Az oltástípusok és az oltással elérendő célok ismerete egy olyan viselkedésmintázatot, ökoszisztémát hoz létre, amelyhez a pszichológia fontos új szempontokkal járulhat hozzá. Jól ismert, hogy az oltásokkal csak akkor érhetjük el az ígért előnyeit, ha az emberi közösségek többsége az oltási ajánlások szerint viselkedik. Az egyes pszichológiai tényezők hatása függ az adott vakcinától, annak ütemezésétől, valamint az oltás szélesebb klinikai és társadalmi kontextusától. Éppen ezért az új oltások bevezetésénél a sikeres vagy kudarcos megvalósítók tapasztalatait is érdemes figyelembe venni, példa erre a humán papillomavírus (HPV) elleni oltás bevezetése az Egyesült Államokban. A HPV-vakcinák elfogadását akadályozta az engedélyeztetés késlekedése, a fertőzés, a vakcina és a szexuális magatartás körüli zavartság, a jogszabályokat övező felháborodás (Colgrove-Abiola-Mello 2010). A felsoroltak mindegyike egy olyan, az ismeretlen helyzetre adott pszichológiai válasz, amely a szülők körében a vakcinával kapcsolatos aggodalommá alakult át. Valójában ezek a pszichológiai válaszok közvetítik a mai napig nem egy országban a HPV-vakcinák elfogadását, s tartják fenn a bizalmatlanságot annak ellenére, hogy nagyszámú adat bizonyítja a vakcina hatékonyságát és biztonságos alkalmazását (Gee et al. 2016). Kérdés tehát, hogy milyen kognitív folyamatok járulnak hozzá ahhoz, hogy egy adott vakcina bekerül a szubjektív elutasítás mozdíthatatlan rendszerébe. Ez a kérdés különösen aktuális 2021 végén, amikor a COVID-19 vakcinákkal szembeni ellenállás igen stabilnak tűnik, mégpedig azon előrejelzések ellenére, amelyek szerint a SARS2 vírusmutációkra fel kell készülnünk.

A pszichológia fóként három fó területen tudja leginkább megfogalmazni javaslatait arra vonatkozóan, hogy miként támogatható az oltási hajlandóság. Ennek persze alapvető feltétele, hogy az oltóanyagok elérhetők legyenek, rendelkezésre álljanak és ingyenesség hiányában megfizethetők legyenek. Bár ez a kitétel redundánsnak tünhet, érdemes figyelembe venni annak a negatív, nemritkán destrukcióban megjelenő pszichológiai válasznak a hatását, amely a vakcinaígéretek elhúzódását kísérheti.

A pszichológiai kutatások azt mutatják, hogy az egyéni válasz szintjén az oltások elfogadását, illetve hasznosságának tagadását a kognitív kiértékelés faktorai (ismeretek, sztereotípiák stb.) és az érzelmi válaszok együtt határozzák meg, s ezek motiválhatják viselkedésünket. Több száz tanulmány igazolja (összefoglalóként lásd Brewer et al. 2017), hogy míg egy adott betegségre vonatkozó negatív elvárásaink mértéke erősen korrelál az oltási hajlandósággal, az oltások hatékonyságába vetett alacsony bizalom és a biztonsággal, megbízhatósággal kapcsolatos aggodalom az oltással szembeni ellenállással jár együtt. 
Az egyén pszichológiai jellemzőin kívül a társadalmi folyamatok motiválhatják az oltási hajlandóságot. Bár minden kutatási eredmény arra utal, hogy a társadalmi normák befolyásolják az oltási hajlandóságot, kevés adat van arra vonatkozóan, hogy a normatív üzenetek növelik-e az oltásfelvételt. Számos tanulmány hipotetikus forgatókönyvekre támaszkodott annak bizonyítására, hogy az altruizmus, valamint a mások által nyújtott védelem kihasználása befolyásolhatja-e a szándékolt viselkedést. Arra is alig található adat a szakirodalomban, hogy a társadalmi folyamatok megváltoztatására kialakított stratégiák növelték-e az oltásfelvételt.

A legtöbbet kutatott terület azokat a pszichológiai faktorokat keresi, amelyekkel a pszichológiai természetú beavatkozás úgy könnyíti meg az oltás elfogadását, hogy kiaknázza, de nem próbálja megváltoztatni az emberek véleményét és érzését. Ezek a beavatkozások a már meglévő, kedvező irányú szándékokra építenek, így megkönnyítik a cselekvést, például emlékeztetők, felhívások, ismertetők segítségével, csökkentik az akadályokat (pl. logisztika). A viselkedést alakító beavatkozások, így az ösztönzők, szankciók és követelmények alkalmazhatósága és hatása erôsen függhet az adott kultúrától. Ebből az is következik, hogy az oltási motiváció növeléséhez szükséges kognitív és érzelmi hatások köre széles, s ezek megváltoztatása a pszichológiai faktorok mélyebb ismerete nélkül nem egyszerú. Kérdés, hogy az ellátórendszer, és egy súlyos helyzet, például pandémia kezelése esetén a döntéshozók számolnak-e ezeknek a faktoroknak a hatásával, s az oltási hajlandóság növelése érdekében építenek-e a pszichológiai alapelvekre.

\section{Aktív közösségi oltásellenesség}

$\mathrm{Az}$ oltásellenes mozgalmak valamilyen formában több mint 200 éve léteznek (Wolfe-Sharp 2002). A radikális csoportok meggyőződése, hogy az oltások nem csupán nem biztonságosak, hanem hatástalanok is. Ettól eltér az úgynevezett reformista csoportok attitüdje, ők ugyanis elfogadják az oltás szükségességét, de jobb teszteket, illetve kompenzációt követelnek az oltás követő káros mellékhatások esetére (Hobson-West 2007). Az oltásellenességhez hozzájárulnak azok a publikációk is, amelyek adott oltáshoz kötik az autizmus spektrum zavart, a serdülőkori autoimmun rendellenességeket. Ezen az sem változtat, hogy a kutatások nem igazolták ezt a kapcsolatot (lásd Maglione et al. 2014).

Az oltásellenesség radikális csoportjainak gondolati építkezése számos olyan jellegzetességet mutat, amelyet sokak számára nehéz lehet felismerni. A tudományos eredmények elfogult újraértékelését elferdített, a szakmai érvrendszerből kiemelt hipotézisekre építik, az eltérő eredményeket, véleményeket ignorálják, figyelmen kívül hagyják, s kritikusaikat személyes sértésekkel és perekkel támadják (Kata 2010). Az oltásellenesség „tudományos” bizonyítékait gyưjtik, s a meglévő aggályokat úgy erősítik, hogy bizonyított tényeket (pl. oltások és hirtelen csecsemőhalál szindróma függetlensége) cáfolnak, és új elméleteket alkotnak (pl. oltások és autizmus; lásd Leask-Chapman-Cooper Robbins 2010).

Azt, hogy mikor és hogyan befolyásolja adott közösség aktív oltásellenessége az egyéni magatartást, még kevéssé értjük, de gyanítjuk, hogy a hatás nemlineáris. Az 1970-es években például az oltásellenes aktivisták több országban is elérték a pertussis (szamárköhögés) programok leállítását (Gangarosa et al. 1998; Poland-Jacobson 2001). Csak egy jelentős morbiditás és mortalitás után állította vissza az érintett nyolc ország az oltási programját.

Az oltásellenesség terjedése pszichológiai szempontból igencsak egyszerú. A vakcinatagadó aktivisták érdekes történetet mesélnek el, míg a hivatalos forrásokból származó üzenetek általában szárazan tényszerűek, nem, vagy nehezen érthetőek, nem elég érdekesek, könnyen felejthetők (Downs-de Bruin-Fischboff 2008; Reyna 2012). Az oltásellenes üzenetek szinte mindig személyes történetekre (áldozatok, hozzátartozók, szemléletesen bemutatott tünetek stb.) építenek, felhasználva azt az ismert pszichológiai tényt, hogy a személyes történetek hatása, s az egyén bevonódása erősebb, mint a nagyobb csoportokra, illetve a népességre vonatkozó statisztikák (Borgida-Nisbett 1977; Kogut-Ritov 2005). Az oltásellenes kommunikáció épít a vélt vagy valós visszaélések hírére, a kormányokkal összeesküvő gyógyszergyárak szándékaira és hasznára, elfedve ezzel minden más információt (Leask-Chapman 1998).

Az oltástagadók egyéni történetei olyan érzelmeket váltanak ki, mint a düh, félelem, sajnálat, valamint az orvossal, egészségüggyel szembeni bizalmatlanság. Mindez felerôsíti azt a szubjektív kockázati észlelést, amelyet eröteljes érzelmi válaszok kísérnek (Loewenstein et al. 2001). Ennek eredményeként az oltásellenes üzenetek érdekesek, emlékezetesek és igényesek.

Az oltási kedv növelése tehát olyan hiteles üzeneteket igényel, amelyek személyesek, érdekesek, egyszerüségükben is emlékezetesek. A digitális információközlés világában fontos, hogy az oltásra felhívó webhelyek ne legyenek gyengébb minőségűek az oltásellenes oldalaknál. Napjainkban még mindig kevés kutatás áll rendelkezésre arról, hogy milyen eszközökkel lehet hatékonyan küzdeni az oltásellenes üzenetek ellen. Egy biztos, az intervencióknak mindenképpen hatniuk kell a bizalom növelésére, s ennek pszichológiai eszköztárára érdemes támaszkodni.

\section{Kockázatészlelés és egészség-magatartás}

A kockázatészlelés empirikus megközelítése annak feltárására irányul, hogy a különböző kockázatértékelések hogyan viszonyulnak egymáshoz. Egy ilyen megközelítés vezetett a hármas kockázatmodell (tri-risk) kialakításához. A modell három olyan egymással összefüggő kockázati komponenst azonosít, amelyek mindegyike egyedülálló prediktív értéket képvisel. Az empirikus 
megközelítés azt vizsgálja, hogy a különböző kockázatértékelések hogyan viszonyulnak egymáshoz. Egy ilyen megközelítés vezetett a tri-risk modellhez, amely három összefüggő kockázati komponenst azonosít, amelyek mindegyikének egyedülálló prediktív értéke van az egészség-magatartás tekintetében (Ferrer et al. 2016). $\mathrm{Az}$ első komponens a tájékozódó kockázatértékelés, amely magában foglalja a valószínú hiedelmeket, így a véletlenre, a valószínúségekre és a kockázatokra vonatkozó hiedelmeket. A második komponens a tapasztalati kockázatértékelés, amely már magában foglalja a korábbi benyomásokat, érzéseket, beleértve a nemtudatos benyomásokat, megérzéseket, érzékenységi meggyőződéseket, az élénkséget és az élményszintû́ benyomásokat. Ez a két komponens elsősorban a vélt kockázati valószínúség és sebezhetôség mutatója. Amint azt fentebb bemutattuk, ezek a hiedelmek összefüggésben állnak az adott közösségben uralkodó nézetekkel, a vélt vagy valós összefüggések befogadásával.

A tri-risk modell harmadik összetevője az affektív kockázat, amely magában foglalja az aggodalmat, a szorongást és a félelmet. Az egészségszorongás oltásra ösztönzi az embereket, így például nagyobb eséllyel veszik fel a szezonális influenzaoltást, ha aggódnak az influenza következményei miatt, vagy arra számítanak, hogy az oltás kisebb kockázattal jár (Chapman-Coups, 2006; Weinstein et al. 2007).

\section{Az egészség-magatartás megbízhatóság aspektusai}

Az egészség-magatartás elméletek, túlmutatva a kockázatészlelés modelljein, a védőhatásról alkotott hiedelmekkel is foglalkoznak. Ezek az egészség-meggyőződés modellekben mint észlelt előny jelennek meg (JanzBecker, 1984), a tervezett viselkedés és indokolt cselekvés elméleteiben pedig attitüdként (Fishbein-Ajzen, 2010). A modellek az egészség-magatartás aktív cselekvést igénylő eseteiben (ilyen az oltás is) az azonosítható, viselkedésesen is megnyilvánuló attitüdöket magabiztosságnak nevezik. Sajnos a meghatározások némileg pontatlanok, de általában azt a meggyőződést sugallják, hogy az orvosi beavatkozások (az oltás is) biztonságosak, és egy megbízható egészégügyi ellátórendszer részét képezik. A bizalom ebben az értelemben magában foglalja az orvosi beavatkozások iránti attitúdöket, és átfedésben van az oltásokba vetett hittel és bizalommal.

$\mathrm{Az}$ orvosi beavatkozások iránti bizalom mérésére szolgáló skálák általában a haszon (észlelt hatékonyság), az ártalom (mellékhatások, biztonság) és a beavatkozást végző személy és intézmény iránti bizalom skáláival operálnak. Egyik jellegzetes példa a bizalmi skála, illetve az immunizációs meggyőződés és attitüd skála (CHIAS; McRee-Reiter-Brewer 2010). Az influenza attitüdskála 17 validált tétele közé tartozik a fertőzés- és a vakcinaészlelés, az egészségügy szereplőibe vetett bizalom és a társadalmi befolyás alskála (Wheelock et al. 2017).
Megállapítható, hogy az egészség-magatartás meglehetősen komplex hatások alatt áll, s ennek pszichológiai faktorai sem teljesen ismertek. Bár a kognitív és affektív aspektusok tanulmányozásával közelebb juthatunk ennek megértéséhez, a súlyos betegségeket (gyermekkori védőoltások) és a járványokat (COVID-19) megelőző, hatásukat enyhító oltások elfogadását célzó beavatkozások hatásmechanizmusainak feltárása még várat magára. A kockázatértékelés és a bizalom, megbízhatóság faktorainak ismerete jó alapot jelenthetnek a jövőbeni beavatkozásokhoz. Ehhez azonban a pszichológiai kutatásoknak több kérdése van, mint válasza. Tudjuk, hogy a fokozott ártalomtól való félelem növeli a helyes egészségügyi magatartás valószínúségét, nem ismerjük viszont, hogy az oltási hajlandóságot milyen körülmények könnyítik, illetve korlátozzák. A COVID-19-járvány tapasztalatai sok országban azt mutatták, hogy a beavatkozások növelték az emberek bizalmát és oltási szándékát. Tény ugyanakkor, hogy az egyes faktoroknak az oltási magatartásra gyakorolt pszichológiai hatása nem teljesen ismert.

\section{Összefoglalás}

Az emberekkel végzett vizsgálatoknak mindig van egy olyan dimenziója, amely az etikus kutatás elvárásain, szabályokban és jogszabályokban rögzített keretein túlmutat. Bár a tudományos kutatásokra az etika szabályai az elsősorban meghatározóak, fontos lenne átgondolni, hogy a tudománynak a felhasználásra vonatkozó morális semlegessége milyen társadalmi kihívásokat jelenthet.

A pszichológiai kutatásoknak szinte mindig meg kell küzdeni valamilyen etikai konfliktussal, s a morális felelősség kérdése is egyre gyakrabban felmerül. Ez a pszichológiai tudomány múvelói számára jól ismert körülmény. Kevésbé magától értetődő viszont, hogy minden, emberekkel végzett kutatásnak vannak az etikán túlmutató pszichológiai aspektusai. Ezek az orvosbiológiai kutatások területén egyértelmúek, különösen, ha a testünket, egészségünket, s ezáltal egészség-magatartásunkat befolyásoló vizsgálatról vagy beavatkozásról van szó. Ebbe a kiemelt körbe tartoznak az egyén egészségdöntéseit befolyásoló genetikai vizsgálatok, jóllehet a populációs genetikai vizsgálatok is gyakran indukálnak pszichológiai természetủ kérdéseket.

Az egészség-magatartást vizsgáló pszichológiai kutatások egyik különleges iránya a védőoltások elfogadását, illetve elutasítását befolyásoló pszichológiai tényezők feltárására fókuszál. Az elmúlt évtized publikált eredményei azt mutatják, hogy az egyéni (kognitív és affektív feldolgozás, kiértékelés) és a társadalmi (szokások, kultúra, döntési mechanizmusok) jellemzők egyaránt befolyásolják a védőoltások különböző típusainak elfogadottságát. Ezen belül külön kategóriát képvisel a járványokhoz kapcsolódó vakcinafejlesztést és -alkalmazást kísérő pszichológiai tényező́k vizsgálata. A COVID-19-járvány az oltási hajlandóság és elutasítás pszichológiai aspektusainak kutatásában különleges szempontokat vet fel, jóllehet 
ennek szisztematikus vizsgálatára vonatkozó adatokkal e tanulmány megírásának idején még nem rendelkezünk. A COVID-19-járvány első hullámai olyan megváltozott pszichológiai megküzdést kívánó helyzeteket hoztak létre, amelyre a pszichológiai kutatások elsősorban a járványhelyzet, a megbetegedés s az abból következően megváltozott életvitel pszichológiai aspektusainak (társas izoláció kezelése, stresszkezelés, szorongás, depresszió) vizsgálatával reagáltak. A járványokra, s az ebből következő veszteségekre (egészség, család, munkahely) adott pszichológiai válaszok kutatása mellett ezért szükség van a védőoltások elfogadásának pszichológiai vizsgálataira is. A kockázatészlelés és a vakcinák elfogadásának pszichológiai faktorainak ismerete hozzájárulhat a globálisan előjelzett járványokra való felkészüléshez és a döntési folyamatok kialakításához.

\section{Irodalomjegyzék}

Borgida, E., \& Nisbett, R. E. (1977) The differential impact of abstract vs. concrete information on decisions. Journal of Applied Social Psychology, Vol. 7. No. 3. pp. 258-271.

Brewer, N. T., Chapman, G. B., Rothman, A. J., Leask, J., \& Kempe, A. (2017) Increasing Vaccination: Putting Psychological Science Into Action. Psychological Science, Vol. 18. No. 3. pp. 149-207.

Cameron L. D., \& Muller C. (2009) Psychosocial aspects of genetic testing. Current Opinion in Psychiatry Vol. 22. No. 2. pp. 218 223.

Chapman, G. B., \& Coups, E. J. (2006) Emotions and preventive health behavior: Worry, regret, and influenza vaccination. Health Psychology, Vol. 25. No. 1. pp. 82-90.

Colgrove, J., Abiola, S., \& Mello, M. M. (2010) HPV vaccination mandates-Lawmaking amid political and scientific controversy. New England Journal of Medicine, Vol. 363. No. 8. pp. 785-791.

Downs, J. S., de Bruin, W. B., \& Fischhoff, B. (2008) Parents' vaccination comprehension and decisions. Vaccine, Vol. 26. No. 12. pp. 1595-1607.

Ferrer, R. A., Klein, W. M. P., Persoskie, A., Avishai-Yitshak, A., \& Sheeran, P. (2016) The tripartite model of risk perception (TRIRISK): Distinguishing deliberative, affective, and experiential components of perceived risk. Annals of Behavioral Medicine, Vol. 50. No. 5. pp. 653-663.

Fishbein, M., \& Ajzen, I. (2010) Predicting and changing behavior: The reasoned action approach. New York, Taylor \& Francis

Gangarosa, E. J., Galazka, A. M., Wolfe, C. R., Phillips, L. M., Gangarosa, R. E., Miller, E., \& Chen, R. T. (1998) Impact of anti-vaccine movements on pertussis control: The untold story. The Lancet, Vol. 351. No. 9099. pp. 356-361.

Gee, J., Weinbaum, C., Sukumaran, L., \& Markowitz, L. E. (2016) Quadrivalent HPV vaccine safety review and safety monitoring plans for nine-valent HPV vaccine in the United States. Human Vaccines \& Immunotherapeutics, Vol. 12. No. 6. pp. 1406-1417.

Heshka J. T., Palleschi C., Howley H., Wilson B., \& Wells P. S. (2008) A systematic review of perceived risks, psychological and behavioral impacts of genetic testing. Genetic Medicine, Vol. 10. No. pp. 1932.

Hobson-West, P. (2007) "Trusting blindly can be the biggest risk of all": Organised resistance to childhood vaccination in the UK. Sociology of Health and Illness, Vol. 29. No. 2. pp. 198-215.

Hollands, G. J., French, D. P., Griffin, S. J., Prevost, A. T., Sutton, S., King, S., \& Marteau, T. M. (2016) The impact of communicating genetic risks of disease on risk-reducing health behaviour: Systematic review with meta-analysis. BMJ, 352.

Janz, N. K., \& Becker, M. H. (1984) The Health Belief Model: A decade later. Health Education Quarterly, Vol. 11. No. 1. pp. 1-47.

Kata, A. (2010) A postmodern Pandora's box: Anti-vaccination misinformation on the Internet. Vaccine, Vol. 28. No. 7. pp. 1709-1716.

Kogut, T., \& Ritov, I. (2005) The "identified victim" effect: An identified group, or just a single individual? Journal of Behavioral Decision Making, Vol. 18. No. 3. pp. 157-167.

Leask, J. A., \& Chapman, S. (1998) An attempt to swindle nature: Press anti-immunisation reportage 1993-1997. Australian and New Zealand Journal of Public Health, Vol. 22. No. pp. 17-26.

Leask, J., Chapman, S., \& Cooper Robbins, S. C. (2010) "All manner of ills": The features of serious diseases attributed to vaccination. Vaccine, Vol. 28. No. 17. pp. 3066-3070.

Loewenstein, G. F., Weber, E. U., Hsee, C. K., \& Welch, N. (2001) Risk as feelings. Psychological Bulletin, Vol. 127. No. 2. pp. 267286.

Maglione, M. A., Das, L., Raaen, L., Smith, A., Chari, R., Newberry, S. ... Gidengil, C. (2014) Safety of vaccines used for routine immunization of US children: A systematic review. Pediatrics, Vol. 134. No. 2. pp. 325-337.

McRee, A-L., Reiter, P. L., \& Brewer, N. T. (2010) Vaccinating adolescent girls against human papillomavirus-Who decides? Preventive Medicine, Vol. 50. No. 4. pp. 213-214.

Middlemist, R., Knowles, E., \& Matter, C. (1976) Personal space invasions in the lavatory: Suggestive evidence for arousal. Journal of Personality and Social Psychology, Vol. 33. No. 5. pp. 541-546.

Milgram, S. (1963) Behavioral Study of Obedience. Journal of Abnormal and Social Psychology, Vol. 67. No. 4. pp. 371-378.

Oliveri, S., Ferrari, F., Manfrinati, A., \& Pravettoni, G. (2018) A Systematic Review of the Psychological Implications of Genetic Testing: A Comparative Analysis Among Cardiovascular, Neurodegenerative and Cancer Diseases. Frontiers in Genetics, Vol. 9. 624.

Oliveri S., Howard H. C., Renzi C., Hansson M. G., \& Pravettoni G. (2016) Anxiety delivered direct-to-consumer: are we asking the right questions about the impacts of DTC genetic testing? Journal of Medical. Genetics, Vol. 53. No. 12. pp. 798-799.

Poland, G. A., \& Jacobson, R. M. (2001) Understanding those who do not understand: A brief review of the anti-vaccine movement. Vaccine, Vol. 19. No. 17-19. pp. 2440-2445.

Reyna, V. F. (2012) Risk perception and communication in vaccination decisions: A fuzzy-trace theory approach. Vaccine, Vol. 30. No. 25. 3790-3797.

Wade, C. H., Shiloh, S., Woolford, S. W., Roberts, J. S., Alford, S. H., Marteau, T. M., \& Biesecker, B. B. (2012) Modelling decisions to undergo genetic testing for susceptibility to common health conditions: an ancillary study of the Multiplex Initiative. Psychological Health Vol. 27. No. 4. pp. 430-444.

Wang, C., O’Neill, S. M., Rothrock, N., Gramling, R., Sen, A., Acheson, L. S. ... Ruffin, M. T. (2009) Comparison of risk perceptions and beliefs across common chronic diseases. PrevMed, Vol. 48. No. 2. pp. 197-202.

Weinstein, N. D., Kwitel, A., McCaul, K. D., Magnan, R. E., Gerrard, M., \& Gibbons, F. X. (2007) Risk perceptions: Assessment and relationship to influenza vaccination. Health Psychology, Vol. 26. No. 2. 146-151.

Wheelock, A., Miraldo, M., Thomson, A., Vincent, C., \& Sevdalis, N. (2017) Evaluating the importance of policy amenable factors in explaining influenza vaccination: A cross-sectional multinational study. BMJ Open, Vol. 7. No. 7. Article e014668.

Wolfe, R. M., \& Sharp, L. K. (2002). Anti-vaccinationists past and present. British Medical Journal, Vol. 325. No. 7361. pp. 430432 .

A cikk a Creative Commons Attribution 4.0 International License (https://creativecommons.org/licenses/by/4.0/) feltételei szerint publikált Open Access közlemény, melynek szellemében a cikk bármilyen médiumban szabadon felhasználható, megosztható és újraközölhető, feltéve, hogy az eredeti szerző és a közlés helye, illetve a CC License linkje és az esetlegesen végrehajtott módositások feltüntetésre kerülnek. (SID_1) 